\title{
LABORATORY DIAGNOSIS OF GLANDULAR FEVER
}

\author{
W. BRumfitT, M.B.(Lond.), M.R.C.P. \\ Wright-Fleming Institute, St. Mary's Hospital Medical School, Paddington, London, W.2 \\ and \\ F. O'Grady, M.D.(Lond.), M.Sc. \\ Bland-Sutton Institute of Pathology, Middlesex Hospital, London, W. I
}

A common feature of the numerous published studies on glandular fever is the wide variation encountered in the clinical and pathological manifestations of the disease (Davidsohn, 1952). This has permitted the clinician to label a wide variety of illnesses as glandular fever even in the presence of persistently negative laboratory findings. It is, therefore, far from clear whether the diagnosis of this condition can be regularly sustained or excluded on laboratory grounds.

The essential problems in attempting to resolve this situation are that more than one group of diseases may be involved and that the diagnosis may not be easily established with certainty in the absence of positive laboratory findings. Attempts to overcome these difficulties have largely depended on the study of outbreaks in which some of the cases show features, clinical or pathological, or both, which make the diagnosis certain, and other cases arising in association with them could be presumed, with reasonable justification, to be suffering from the same condition. Some doubt has been cast on the value of this procedure in the study of sero-positive glandular fever by the work of Shubert and his colleagues (1954) who presented evidence that in epidemic glandular fever sheep-cell agglutinating antibody did not appear.

Contrary to these findings we have observed an outbreak of sero-positive disease the study of which, in conjunction with the findings of previous workers, suggests certain generalizations about the laboratory findings in glandular fever which go some way towards establishing criteria for the laboratory diagnosis or exclusion of this condition.

\section{Materials and Methods}

Within a period of five weeks during September and October the small proportion of febrile patients admitted to the Cambridge Military Hospital, who were diagnosed as suffering from glandular fever, increased rapidly to epidemic proportions. Together with those suffering from the fully developed syndrome, a large number of their contacts were taken ill at the same time with much less specific illnesses.

All those were included in the series who showed the typical disease with fever, sore throat, headache, malaise and widespread lymphadenopathy, or who developed acute febrile illnesses in immediate association with such patients. In the inclusion of cases no reference was made to laboratory findings, although it was known from preliminary study of the earlier cases that some were sero-positive. In this way a group of 54 cases diagnosed on clinical or epidemiological grounds as glandular fever was collected.

In each of these the following pathological tests were conducted on admission: haemoglobin, total and differential white cell count, throat swab, and Paul Bunnell test. The haematological examinations were repeated every three or four days. Abnormal leucocytes were classified according to Downey and MacKinley (1923). Sera were screened for sheep-cell agglutinating antibody by a slide test (Vaughn, I95 I ; Brumfitt, and O'Grady, 1957) and the absorption pattern of positive sera determined by a modification of the method of Davidsohn (1937). The E.S.R. (Westergren) was determined in half the cases and all these tests were repeated three weeks after discharge.

In 26 cases, acute and convalescent phase sera were examined for antibodies to influenza A, B and C, psittacosis L.G.V., Q fever and streptococcus M.G. Virus isolation was attempted in eight early cases. The thymol turbidity test and urinary urobilinogen examination were carried out in $3 \mathrm{I}$ cases and supplemented, where indicated, by further tests of liver function.

\section{Results}

No abnormality of the platelets and no anaemia during either the acute or convalescent stages of the disease were found.

\section{White Cell Counts}

The maximum circulating numbers of total 
TABLE I

Numbers of patients with the following maximal absolute counts in thousands per cu. mm.

\begin{tabular}{c|c|c|}
\hline No. of cells per cu. mm. & Total W.B.C. & Neutrophils \\
\hline$>16,000$ & 11 & 2 \\
\hline $14,100-16,000$ & 6 & - \\
\hline $12,100-14,000$ & 1 \\
\hline $10,100-12,000$ & 10 \\
\hline $8,100-10,000$ & 14 \\
\hline $6,100-8,000$ & 7 \\
\hline $4,100-6,000$ & - \\
\hline $2,100-4,000$ & - & 21 \\
\hline $0-2,000$ & - & 16 \\
\hline
\end{tabular}

$\mid$\begin{tabular}{c}
$\begin{array}{c}\text { Lymphocytes } \\
\text { (including } \\
\text { abnormal cells) }\end{array}$ \\
\hline 2 \\
\hline- \\
\hline 1 \\
\hline 3 \\
\hline 4 \\
\hline 6 \\
\hline 27 \\
\hline-
\end{tabular}

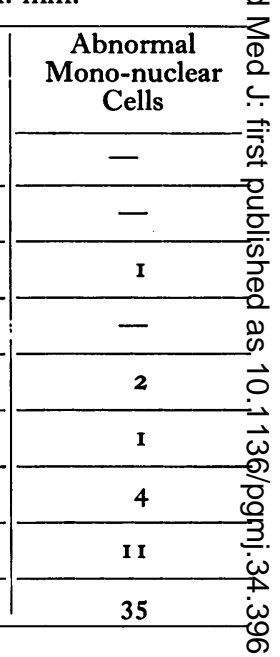

white cells, polymorpho-nuclear neutrophils, lymphocytes and abnormal mononuclear cells are summarized in Table $\mathrm{I}$. The majority of patients had normal total white cell counts when first seen. Most of the white cell counts which were raised or became so had returned to normal when seen three weeks after discharge. A lymphocytosis was the rule from the onset; although most patients were examined within 24 hours of onset, an initial polymorpho-nuclear leucocytosis was seldom seen.

\section{Abnormal Cells}

All patients showed ro per cent. or more of abnormal mononuclears in the peripheral blood at some stage of the disease. The number of circulating abnormal cells was frequently maximal on, or within two to three days of, admission. Downey Type I cells predominated in 84 per cent. of the patients and Downey Type 2 cells in the remainder. No cells of Downey Type 3 were seen.

\section{Paul Bunnell Test}

The maximal absorbed Paul Bunnell titres are shown in Table 2 and the relation to maximal abnormal cell count and clinical condition in Figs. $\mathbf{I}$ and 2.

\section{Bacteriology of Throat Swabs}

Beta haemolytic streptococci were isolated from six cases. In only one case was the organism found to belong to Lancefield group A. No other bacterial pathogens were found.

\section{Virus Studies}

None of the cases showed a significant or rising titre of antibodies. From one case influenza B
TABLE 2

Relation between thymol turbidity and Paul Bunnel titre in 31 patients

\begin{tabular}{|c|c|c|c|c|}
\hline \multirow{3}{*}{$\begin{array}{c}\text { Thymol } \\
\text { Turbidity } \\
\text { Units } \\
\text { I-2 }\end{array}$} & \multicolumn{4}{|c|}{ Absorbed Paul Bunnell Titre } \\
\hline & $10-20$ & $40-80$ & $160-320$ & $640-2560^{\circ}$ \\
\hline & 7 & 6 & 2 & $1 \leqq \infty$ \\
\hline $3-4$ & 2 & 5 & $\mathbf{I}$ & - \\
\hline $5^{-6}$ & 2 & - & - & 4 \\
\hline $7-8$ & 一 & - & - & $\mathbf{I}$ \\
\hline
\end{tabular}

virus was isolated from throat washings. No other viruses were isolated.

E.S.R.

Of the 28 cases investigated, two had E.S.R.s. (Westergren) of more than $40 \mathrm{~mm}$. in the firse. hour and both had radiologically confirmed ches 5 complications. Of the remainder, 18 had E.S.R.S between 20 and $40 \mathrm{~mm}$. in the first hour.

\section{Thymol Turbidity}

Serum from $3 \mathrm{I}$ consecutive patients was ex amined. Seven (22.5 per cent.) showed abnormaP (more than four units) thymol turbidity tests. In five the Paul Bunnell titre was $1: 320$ or more, and in two $1: 5$, one of these being a typical case of glandular fever. A comparison of the thymol tur bidity and Paul Bunnell results is given in Table $2 \frac{\mathscr{\mathbb { D }}}{\mathscr{C}}$

\section{Discussion}

The diagnosis of glandular fever is based or? 
three findings: (r) the clinical picture; (2) lymphocytosis with abnormal mononuclear cells in the peripheral blood; (3) the presence of sheep-cell agglutinating antibody.

\section{Clinical Picture}

The wide variety of the clinical manifestations of the disease and the non-specific nature of milder attacks (Press et al., 1945; Tidy, 1952) make it impossible to diagnose this condition with any certainty on clinical grounds alone except in the most typical cases or during epidemics (Bernstein, 1940).

\section{Lymphocytosis}

This is a common and frequently early finding in the peripheral blood in glandular fever. However, like the total leucocytosis which is often found, lymphocytosis can be of no diagnostic value unless it can be shown to be of a certain minimum magnitude. The diagnosis can then at least be excluded in those failing to show a response. Bayrd (1956) claimed that 50 per cent. lymphocytosis (including abnormal cells) was an invariable finding in this condition within the first ten days. In their outbreak Shubert and his colleagues (1954) were unable to confirm this, but found a maximal lymphocytosis of 4,000 per c.mm. or more in all cases. In the present series, not even these unremarkable values have been universally achieved.

From Table $I$ it will be seen that, in fact, the distribution of maximal lymphocyte counts differed very little from that of the polymorphs. We have only occasionally seen, however, both in this series and in numerous endemic cases, the initial polymorphonuclear leucocytosis which is described (Whitby and Britton, I953). In the present cases the polymorph response to secondary infection was unimpaired and the highest polymorph counts were associated with secondary pulmonary infection.

\section{Abnormal Mononuclear Cells}

The belief that glandular fever can be diagnosed by the demonstration in the peripheral blood of certain types of abnormal mononuclear cell has been widely criticized on the grounds that similar cells have been shown to occur in many other conditions. The possibility that the cells present in other conditions might be morphologically distinct from those appearing in glandular fever cannot be upheld. There is no doubt that in a variety of conditions, some of which may lend themselves to clinical confusion with glandular fever, cells indistinguishable from those described by Downey and MacKinley (1923) may be found (Warren, 194I; Randolf and Gibson, 1944; Havens and
Marck, I949). In these conditions, however, the maximum number of cells found is invariably less than in glandular fever. Like Gardner and Paul (1947), we have found the number of glandular fever type cells to be less than ro per cent. in other conditions which we have examined. Both in the cases of Shubert and his colleagues (1954) and in the present series, no case of glandular fever'had persistently less than 1o per cent. of abnormal mononuclear cells.

It appears, therefore, that in both sero-positive and sero-negative glandular fever more than ro per cent. of the mononuclear cells show the abnormalities described by Downey and MacKinley, whereas in other conditions this number of cells is never seen. The diagnostic value of the absolute numbers of abnormal cells is less. In the present series, eight cases persistently showed less than I,, 00 abnormal mononuclear cells per c.mm., and of these only two had an absolute lymphocytosis in excess of 4,000 per c.mm. More than one type of Downey cell is usually present, but in genuine cases one type predominates. In all the cases we have studied the maximum number of abnormal mononuclear cells appeared within a week of onset of symptoms. It is essential, therefore, to examine the blood at this time. Contrary to the findings of Van Ravenswaay (1934) and Wechsler et al. (1946), we have found that if cells fail to appear in the first week of the illness further search is likely to be unrewarding.

\section{Paul Bunnell Test}

The diagnostic importance of the Paul Bunnell test has been challenged on two grounds. It has been held that in a number of genuine cases the test is repeatedly negative (Kaufmann, 1944; Press et al., 1945), and also that it may be positive to high titre in a number of other conditions (Bernstein, 1940; Schultz, 1948; Leibowitz, 1953). There is, at present, no simple way of resolving the first difficulty. Although some authors insist that glandular fever must not be diagnosed unless the serological test is positive (Hoagland, 1952; Leibowitz, I953), it must be accepted that cases occur in which, despite careful and repeated study, sheep-cell agglutinating antibody cannot be demonstrated. This has led a number of authors (Davidsohn, 1937; Fuller, 194I) to postulate that the diseases differ in etiology, and Shubert and his colleagues (1954) have attempted to distinguish the sero-negative disease as epidemic and the seropositive as endemic; this distinction cannot be maintained in face of the present findings. Shubert claims that sero-negative cases commonly show rashes, while sero-positive cases do not. We found no rashes amongst our sero-positive cases and hence the presence or absence of a rash may 


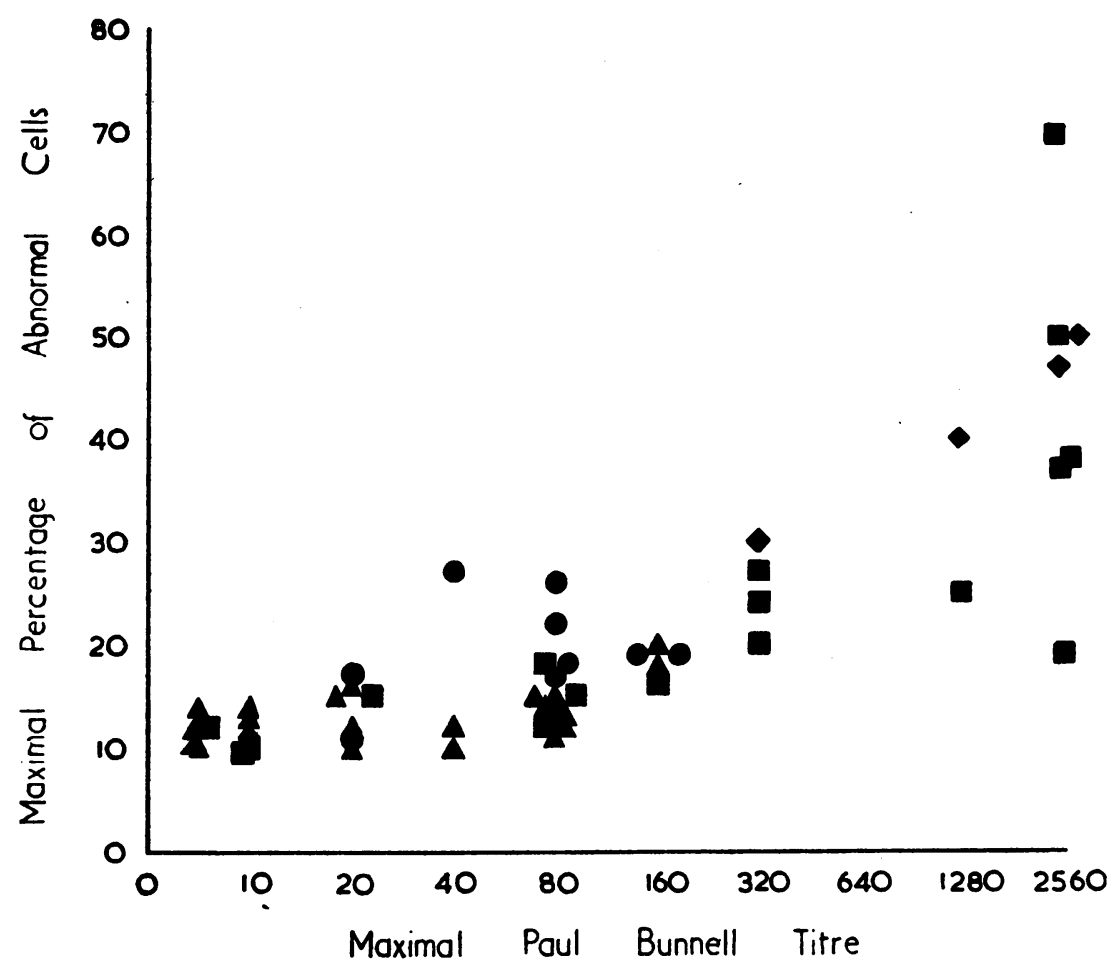

Fig. 1.-Comparison of maximal Paul Bunnell titres, maximal percentage of abnormal cells, and clinical condition.

- Cases with fever, exudative tonsillitis and gross generalized lymphadenopathy.

- Cases with fever, exudative tonsillitis and gross generalized lymphadenopathy and splenomegaly.

$\Delta$ Cases with fever, mild, or moderate generalized lymphadenopathy or localized lymphadenopathy.

- Cases with fever, upper respiratory tract symptoms, and minimal lymphadenopathy.

help in deciding whether a case is likely to be seropositive.

The specificity of the Paul Bunnell test is a much clearer issue. While it is certainly true that in a number of unrelated conditions, some of which may be possibly confused clinically with glandular fever, the Paul Bunnell may be positive even to high titre (Bernstein, 1940; Schultz, 1948) in all these conditions the antibody is of the Forssman type (Eaton et al., 1944; Kaufmann, 1944; Leibowitz, 1951). Any antibody remaining after guinea-pig kidney absorption, therefore, is of the type associated with glandular fever. In deciding the question of diagnostic titre one other group of observations must be considered. Halcrow et al. (1943), Van der Meer et al. (1945) and Watson et al. (195I) have found both glandular fever type antibodies and typical haematological findings in a number of symptomless individuals. All of these subjects were, however, contacts of cases of glandular fever and can, therefore, be regarded as sub-clinical cases. The evidence suggests that in other conditions and in non-contact normal subs jects glandular fever type antibody very rare exceeds $1: 56$ (Kaufmann, 1944; Goldman et ap. 1950; Leibowitz, 195I). Both Kaufmann (194\$) and Leibowitz (195I) have drawn attention to the influence on the titre of modifications in technique and the importance of repeated examination must again be emphasized. Circulating antibody may present for a short time only (Rapaport, 1948) or may appear late in the disease or even in con valescence (Press et al., r945; Himsworth, 1948 Kaufmann, 1944). In accord with the findings \&f other workers (Kaufmann, 1944; Press et aN 1945; Tidy, 1952), there is no relationship in the present cases between the antibody response an the manifestations or severity of the disease (Figg. 1 and 2).

Relation of Paul Bunnell Titre to Abnormal Cells

In the present cases there is a clear relationship between the maximal percentage of circulating abnormal mononuclear cells and the maxims 


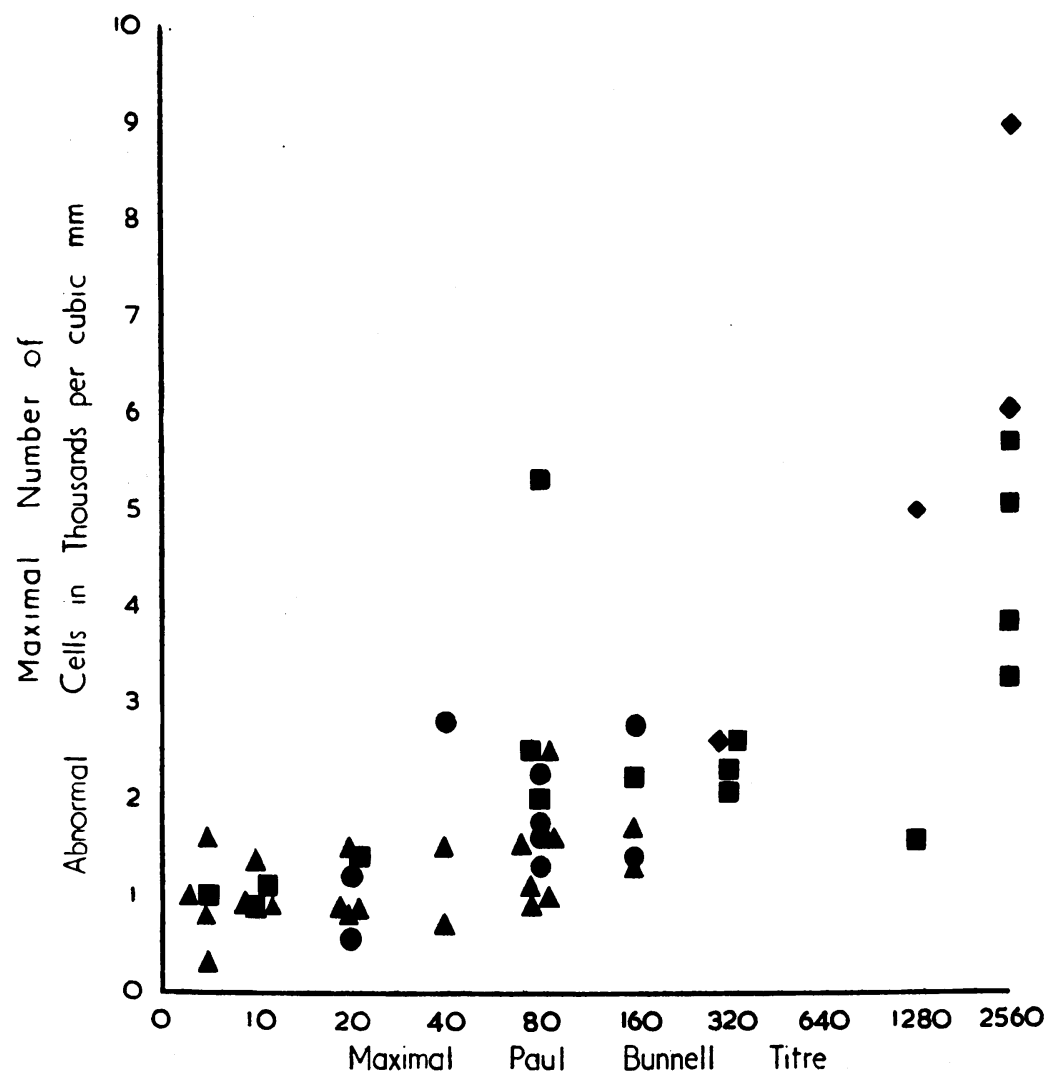

Fig. 2.-Comparison of maximal Paul Bunnell titres, maximal absolute abnormal cell counts, and clinical condition. Cases and Symbols as in Fig. I.

absorbed Paul Bunnell titre (Fig. I). These two maxima did not necessarily occur together. The relationship between the Paul Bunnell titre and absolute abnormal mononucleosis is less distinct (Fig. 2). A relationship of this kind has been previously denied by Van Ravenswaay (1934) and Bernstein (1940).

\section{Thymol Turbidity}

This test has been recommended as a useful adjunct in the diagnosis of glandular fever (Evans, 1948; Iversen and Raaschou, 1948). In the present series (Table 2) seven out of $3 I$ cases examined gave thymol turbidities of more than four units. Of these, five had very high absorbed Paul Bunnell titres and one of the other two cases with a low titre was clinically a typical case. Clearly, however, in this condition the diagnostic possibilities of the test are limited.

\section{Laboratory Diagnosis}

It appears that, provided early and repeated ex- aminations are undertaken, glandular fever can be diagnosed or excluded in the laboratory with some confidence. The important, pathognomonic finding is the presence in the peripheral blood, usually within a week of the onset of symptoms, of ro per cent. or more of Downey type abnormal mononuclear cells. Sheep-cell agglutinating antibodies may or may not appear, but antibody which is not absorbed by guinea-pig kidney is characteristic of glandular fever and a titre of $1: 56$ or more is diagnostic. High titres of antibody are likely to occur only in those with large numbers of cir? culating abnormal cells.

\section{Summary}

I. An outbreak of sero-positive glandular fever is described.

2. It could not be confirmed that the degree of lymphocytosis always exceeds certain values in this condition.

3. All the patients had more than ro per cent. of abnormal mononuclear cells in the peripheral 
blood at some stage, usually within a week of the onset of symptoms.

4. The maximal values of glandular fever type sheep-cell agglutinating antibody were related to the maximal percentages of abnormal cells in the peripheral blood.

5. The thymol turbidity test was of limited diagnostic value in this series.

6. It is suggested (a) that the finding of ro per cent. of Downey type cells in the peripheral blood is pathognomonic of glandular fever; (b) that high titres of glandular fever type sheep-cell agglutinating antibody only occur in association with large numbers of abnormal cells; (c) that in certain cases of glandular fever sheep-cell agglutinating antibody may not appear even in the presence of many abnormal cells.

\section{REFERENCES}

BAYRD, E. D. (1956), Med. Clin. N. Amer., 40, I09r. BERNSTEIN, A. (1940), Medicine (Baltimore), 19, 85 .

BRUMFITT, W., and O'GRADY, F. (1957), Ұ. clin. Path., 10, 243. DAVIDSOHN, I. (1937), f. Amer. med. Ass., 108, 289.

DAVIDSOHN, I. (1952), 'Textbook of Clinical Pathology,' 4th edition, edited by Miller, S. E., p. 248.

DOWNEY, H., and MACKINLEY, C. A. (1923), Arch. int. Med., 32, 82.

EATON, M. D., MURPHY, W. D., and HANFORD, V. L. (1944), F. exp. Med., 79, 539.
EVANS, A. S. (1948), f. clin. Int iest., 27, 106.

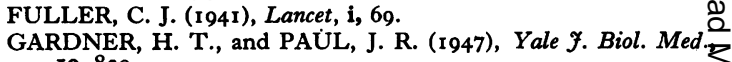
19, 839 .

GOLDMAN, R., FISHKIN, B. G., and PETERSON, E. T路 (1950), Ұ. Lab. clin. Med., 35, 68r. HALCROW, J. P. A., OWEN, L. M., and RODGER, N. O. (1943), Brit. med. f., 2, 443 .

HAVENS, W. P., Jr., and MARCK, R. E. (1949), Amer. F. med? Sci., 212, 129.

HIMSWORTH, H. P. (1940), Lancet, i, 1082.

HOAGLAND, R. J. (1952), Amer. F. Med., 13, 58.

IVERSEN, K., and RAASCHOU, F. (1948), Arch. int. Med., 8x $25 \mathrm{I}$

KAUFMANN, R. E. (1944), Ann. int. Med., 21, 230.

LEIBOWITZ, S. (1951), Amer. F. clin. Path., 21, 201.

LEIBOWITZ S. (1953), 'Infectious Mononucleosis,' Moder Medical Monographs, Grune and Stratton, N.Y., p. I 6.

PRESS, J. H., SHLEVIN, E. L., and ROSEN, A. P. (1945), Ann. int. Med., 22, 546.

RANDOLF, T. G., and GIBSON, E. B. (1944), Amer. F. med. Sci.̦ড, 207, 638

RAPAPORT, S. I. (1948), Ann. West. Med. Surg., 2, 543.

SCHULTZ, L. E. (1948), Arch. inn. Med., 81, 328. SHUBERT, S., COLLEE, J. G., and SMITH, B. J. (1954), Brit.

TIDY, H. (1952), Brit. med. F., 2, 436.

VAN DER MEER, R., LUTTERLUCH, C. H., and PILOT, (1945), Amer. Э. med. Sci., $210,765$.

VAN RAVENSWAAY, A. C. (1934), New Engl. F. Med., 211 , Ioori

VAUGHN, J. (1951), f. clin. Path., 4, 104.

WARREN, E. W. (I94I), Amer. F. med. Sci., 201, 483.

WATSON, J., JOHNSON, P., KAHN, J., STONE, F. M. S(195 I), Arch. int. Med., 88, 618.

WECHSLER, H. F., ROSENBLUM, A. H., and SILLS, C. T $\vec{\odot}$ (1946), Ant. int. Med., 25, II3.

WHITBY, L. E. H., and BRITTON, C. J. C. (1953), ' Disorders of the Blood,' London, Churchill, 7 th edition, p. 607.

\section{BAHLLIËE, TINDALL \& COX}

\section{Pharmacologic Principles of Medical Practice \\ By J. C. KRANTZ, Ph.D., and C. J. CARR, Ph.D. \\ Fourth Edition. 1,324 pages. 83 illustrations. 4 coloured plates and 107 other illustrations. Price I12s. Postage 2s. 9d.}

\section{Textbook of Virology for Students and Practitioners of Medicine}

By A. I. RHODES, M.D., F.R.C.P. (Ed.), F.R.S.C. and C. E. VAN ROOYAN, M.D., D.Sc. (Ed.), M.R.C.P. (Lond.). Third Edition. 658 pages. 81 illustrations. Price 803. Postage 2s. $9 \mathrm{~d}$.

The Measurement and Appraisal of Adult Intelligence

BY D. WECHSLER.

Fourth Edition. 306 pages. 16 illustrations. Price 40s. Postage 2s. 3d.

\section{Applied Physiology of the Eye}

By H. WILLOUGHBY LYLE, B.S., M.D., F.R.C.S., and T. KEITH LYLE, C.B.E., M.D., M.Chir., M.R.C.P., F.R.C.S 350 pages. 32 illustrations. Price 45s. Postage 2s. 3d.

\section{A Modern Practice of Obstetrics}

By D. M. STERN, M.A., M.B., B.Ch., F.R.C.S., F.R.C.O.G., and C. W. F. BURNETT, M.D., F.R.C.S., F.R.C.O.G. Second Edition. 268 pages. 141 illustrations. Price 45 s. Postage 2s. 3d.

\section{Whitla's Dictionary of Medical Treatment \\ Edited by R. S. ALLISON V.R.D. M.D. F.R.C.P., D.P.M and T. H. CROZIER, M.D., B.SC., F.R.C.P., with 26 contributors. \\ Ninth Edition. 870 pages. Price 52s. 6d. Postage 2s. 6d.}

\section{The Clinical Roentgenology of the Digestive Tract}

By N. FELDMAN, M.D.

Fourth Edition. 788 pages. 504 illustrations. Price 120s. Postage 2s. 9d.

\section{Chemistry and Chemotherapy of Tuberculosis}

By E. R. LONG, M.D., Ph.D., Sc.D.

Third Edition. 468 pages. 10 illustrations. Price 963. Postage 2s. 3d.

\section{The Brain and Human Behaviour}

(Proceedings of the A.R.N.M.D./Vol, 36.)

576 pages. 203 illustrations. Price 120s. Postage 2s. 9d.

\section{Applied Foot Roentgenology}

By F. O. GAMBLE, D.S.C., F.A.S.C.R.

426 pages. 411 line drawings, photographs and skiagrams.

Price 120s. Postage 2s. 9d. 